\title{
Geopolitics of the High North and its consequences ${ }^{1}$
}

\author{
Ryszard M. Czarny²
}

\begin{abstract}
The increased interest in the Arctic by global players is generated by new economic opportunities related to commercial maritime transport, development of oil and gas deposits, mining, fisheries, and tourism. The natural results are closer economic and geopolitical relations between the Arctic and the rest of the world. Many observers perceive this development as a source of growing conflict because of competition related to control over the natural resources of the region. It seems also quite clear that the Arctic cannot follow its own original way of development which would be independent from the global power system.
\end{abstract}

Keywords: Arctic; "Arctic Eight"; "Arctic Five"; delimitation; military presence; protecting own sovereignty; cooperation and coordination

\section{Introduction}

The development and evolution of the international community have a natural influence on the condition of the region as a whole, and impact the cooperation of all associated stakeholders who are subjects of international law. The currently binding world order exerts more influence than ever before. Two decades after the end of the Cold War, the trans-border exchange between Russia and its Arctic neighbors, after a slow start and not very promising beginnings, is finally gaining momentum and shows signs of improvement and growth. It is growing on political, cultural, and economic levels (see Total Economy Database, 2008). The consecutive stages of the European Union enlargement have opened new horizons for cooperation and brought new issues to the daily agenda (see Eðvarðsson, 2007). They are of utmost interest and the much diversified activities of several countries are a response to the call of the moment and the necessity of meeting new challenges, and that engagement seems to exhibit richness of thematic range and proves the great attentiveness

1 Parts of this article were published in the book The High North: Between Geography and Politics By Ryszard M. Czarny, Springer International Publishing, 2015, ISBN 9783-319-21661-4, 244 pages.

2 Address: prof. Dr. Ryszard Czarny, PhD., Department of Political Science and European Studies, Faculty of Social Sciences at University of Ss. Cyril and Methodius in Trnava, Bučianska 4/A, 91701 Trnava, Slovak Republic. E-mail: ryszard.czarny@ucm.sk 
(see Ketels, 2008). All that concerns not only the obviously engaged states like the Nordic countries or Russia but also a number of seemingly indirectly involved state or non-state players of the contemporary international scene, including the growing economies of Asia which began articulating their vital interest in the Arctic and the European High North. The activities comprise joint work, cooperation with the regional organizations and on projects created, among others, by the European Union or concerning it, as well as exchange of points of view on the specific issues of the High North. In practice, this proves real interest and not only political rhetoric, and that clearly verifies the significant potential of the region and its great opportunities for economic growth in at least some sectors of economy.

Since the region evokes so much interest, I have decided to present the European High North in this work, with its range of opportunities, great chances of development, but also its potential of generating conflicts not only for the northern part of our globe. Fully aware that the issues are dynamic and therefore evolving, and that tomorrow may bring new developments, i.e. without the time perspective allowing for a scholarly diligent analysis so much enjoyed by historians, I have decided to focus on a few fundamental problems:

-the globalization processes;

-country's demand;

-who does the Arctic belong to

and last but not least:

- the need for international cooperation and coordination.

\section{The globalization processes}

Due to the impact of climate changes, one can say that a notion of a separate Arctic Region not only took on a full shape in the last years, but also currently enjoys a certain revival. Historically, it dates back to several different concepts from the time of great discoveries, through the militarization of the Cold War, all the way to a period of a near oblivion in the post-Cold War era. Today, the situation has taken a diametrical transformation. Climate changes together with the dynamics of rapidly modified assessments of the geopolitical situation in the world are the reasons for redefining the interests of several states vis-àvis the High North.

Although the High North is one of the most remote and inaccessible parts of the world, the Arctic does not appear to be immune to the globalization processes. It is clearly evidenced by new challenges faced by the region's population and the manner in which the region is integrated with the geopolitics on a global 
scale. The emergence of big new consumer markets, mostly in China and India, points to the shift in the dynamics of economic potential and the resulting transformation in terms of security. The occurring changes which allow for utilizing new maritime routes and the decisions delimitating maritime borders in the North may have tremendous implications, for example in the Strait of Hormuz, which in conjunction with the natural resources of the Arctic could have far-reaching consequences for the economies and societies of Asia and Africa. Although the posed hypothesis may appear somewhat futuristic, such a scenario is as possible as predicting a close relationship between melting of the ice in the Arctic and the processes of change in international business and political economy. All of the above is key and fundamental in understanding the dynamic changes leading to the shaping of a new world order in which the North already participates and might soon play a very significant role.

The High North in the political sense denotes eight states, called also the Arctic Eight, two autonomous areas and an archipelago under the auspices of an international agreement. These are six European countries: Denmark (including Greenland and the Faroe Islands), Finland, Iceland, Norway (together with Svalbard), Russia, Sweden, and two non-European states: USA (Alaska) and Canada.

Osica (2010) distinguishes three basic groups among them and their distinct approaches:

- Russia and Canada are the "Arctic Warriors" treating "...their presence in the Arctic as one of the main elements of the identity of their foreign policies, and the one determining their role in the international policy";

- the Nordic states - the "anxious pragmatists" for whom "...the Arctic is an area which determines social and economic development as well as an ecological challenge, and of which Norway is at the forefront. Nordic states are favorably inclined towards involvement of the EU and NATO as organizations which strengthen their positions in relation to the bigger players, particularly Russia and the USA";

- the United States of America - the "late player" "... who has only recently begun the process of defining its interests towards the subregion" (all citations from Osica, 2010, p. 20).

The Arctic ice is really melting: in summer, the ice sheet is $40 \%$ smaller than at any time in more than 30 years of satellite observations. The landscape of the Arctic has been undergoing dramatic changes. When the polar region becomes completely ice-free in the summer months, and experts estimate that it may happen in some 20-30 years, serious international problems may arise. We are already dealing with their harbinger when we ask a question: 
Are the huge deposits of carbohydrates in the High North going to become a source of conflict? After all, we know that together with the decrease or even disappearance altogether of the ice cover, the exploitation of the precious resources will not only become possible but will also rapidly accelerate. "It also means tensions over Arctic real estate. What the Middle East was to the second half of the $20^{\text {th }}$ century, the Arctic could be to the first half of the $21^{\text {st }}$," said the American Christian Science Monitor (quoted after Piaseczny, 2010).

Today, we have really five so far unofficial competitors that are actually taking part in this race: Russia, Canada, USA, Norway, and Denmark. ${ }^{3}$ Russia is already well-equipped for the exploration of the Arctic. On the one hand, it possesses research submarines of the "Mir" class and powerful icebreakers which at any given time may set off on a polar patrol, ${ }^{4}$ but on the other, it does not have the technology or the sufficient capital ${ }^{5}$ to start the extraction of the Arctic resources on a big scale. ${ }^{6}$ Russia has a very long coastline in the High North and still makes demands to a great portion of the Arctic (1.2 million square km, including the North Pole itself). To understand Russia's approach to the Arctic issue, one needs to have at a least a quick look at the history of its activities in the region. In 1926, the Council of People's Commissars of the Union of the Soviet Socialist Republics issued a decree ${ }^{7}$ through which it assumed possession of the islands and the lands, both those already discovered and not yet described, which at the time of signing the decree had not been appropriated by any other country (res nullus) and were situated in the Arctic Ocean within a sector delimitated by two longitudes drawn from the continental coast of the USSR to the North Pole. It is important here that the declaration applied only to land territories and never mentioned the Arctic waters or the continental shelf (Kubiak, 2012, p. 224). The decree formed the basis for the Russian claims in the Arctic and led to a diplomatic dispute with Norway on

3 For a number of reasons, the Russian Federation appears to have the greatest appetite and the biggest assets.

4 A construction of three more nuclear-powered icebreakers is planned. Moscow also intends to create a group of satellites to observe climate changes and explore the High North, searching for minerals.

5 Only the cost of preparations for the exploitation was estimated at 500 billion dollars, while the real amount necessary for industrial extraction stands at 2 trillion dollars; after: Cheda 2013.

6 Both Gazprom and Rosneft are fully aware of that, the more so as together with the thawing of permafrost, the Russian infrastructure beyond the polar circle becomes very vulnerable.

7 The decision was inspired by the Canadian declaration of 1925 extending its maritime boundaries of the "Arctic pie" from its coast northward to the North Pole. 
the delimitation of maritime boundaries in the Barents Sea. On the turn of 1980 s, the eastern frontier of the Russian claims was contested and bred a conflict with the United States over the delimitation of maritime boundaries in the Chukchi Sea. The dispute lasted until July 1, 1990 when the two countries signed an agreement recognizing the "Western frontier" as delineated by the sale of Alaska treaty in $1867 .{ }^{8}$

\section{Country's demand}

With the advancement of new technologies for marine resources development and the somewhat lacking development of the legal framework on the sea, the Russian Federation needed to meet the challenge of securing its claim to the Arctic continental shelf. On December 20, 2001, Russia as the first state in the region submitted an Arctic claim to the UN Commission on the Limits of the Continental Shelf(CLCS) to extend its maritime boundary beyond the limits of 200 nautical miles of the continental shelf baseline. ${ }^{9}$ The argument supporting Russia's demand was the $1800 \mathrm{~km}$ long underwater mountain ridge in the Arctic Ocean from the Siberian continental shelf to the North Pole (Młynarski, 2011, pp. 280-281).

Currently, another Russia's claim is being considered. The country continues to try to find justification by all possible means. On March 2010, Dmitry Medvedev at the session of Russia's Security Council stated that other polar nations had already taken active steps to expand their scientific research as well as economic and even military presence in the Arctic. He also added that attempts had been made to limit Russia's access to the Arctic resources. He commented that it was absolutely inadmissible from the legal viewpoint and unfair given Russia's geographical location and history. Although the Russian leader never named a specific nation, immediately Catherine Loubier, a spokeswoman for Canadian Foreign Minister, said that Canada's sovereignty over lands, islands and waters of the Canadian Arctic is long-standing, wellestablished and based on historical title. She also announced that Canada has committed to building a High Arctic research station that will continue to map Canadian northern resources and waters.

Canada openly disapproves of the Arctic ambitions of Russia and the United States. ${ }^{10}$ The authorities from Ottawa announced also the building of a new deep-

8 It should be noted that the treaty has never been ratified; see also Kubiak, 2012, pp. 226-227.

9 It was not accepted then due to the lack of proper documentation.

10 Canada and the United States have a dispute over the borderline in the Beaufort Sea. 
sea port, patrol ships and a new icebreaker, the John G. Diefenbaker. Experts, however, are of the opinion that even if all these projects are realized, that might not be enough for Canada to become an Arctic power. It is conceivable that in the long run the Canadians will have to acknowledge the superiority of Russia and the United States, although the US, still underappreciating the phenomenon of the global warming, so far seems to be lagging behind in the race for the Arctic resources. "If there's a five-nation race in the Arctic," warns Coast Guard Admiral Gene Brooks, "...we're fifth. Most Americans don't even realize that we are an Arctic nation." $"$ One needs to keep in mind that the US is a superpower and should it choose to make serious claims, the High North might get not warmer but extremely hot.

As mentioned before, Denmark has claims as regards the High North by virtue of Greenland. In spite of several Danish research projects in the making, even if their results could possibly justify the claims of extending Danish sovereignty over additional polar territories, the Kingdom can certainly expect serious objections from Russia and Canada. On 25 November 2008, 75.5\% of the electorate of the world's largest island voted in favor of loosening their 300-year-old ties with Denmark, which may lead to eventual independence. The ambitions of Greenlanders connected with broader autonomy were to be kept in check by the agreement signed with Denmark in 2008, after three years of negotiations, which has provisions on sharing the expected revenues from the exploitation of Arctic resources. The agreement provides for the transfer of 10 million euro annually to Greenland (Truc, 2008).

\section{Plans for a military presence in the Arctic}

If we complement the above, possibly complicating it as well, by a statement that an ice-free Arctic is not only a source of various mineral riches but also a shipping route, it is no wonder then that there are so many comments and opinions that the conflicts over delimitation of the Arctic might lead to military confrontations or at least to a growing international tension in the region (see Luszczuk, 2010). Professor Robert Huebert, of the University of Calgary and an adviser to the Canadian government, described it in the following way: "We are already in an Arctic arms race. The year 2010 in the Arctic is akin to 1935 in Europe" (quoted after Piaseczny, 2010).

It is quite interesting that nearly every country of the region has its own

11 Statement by Rear Admiral Gene Brooks, commander of the U.S. Coast Guard. Quoted after: Piaseczny, 2010. 
plans for a military presence in the Arctic. ${ }^{12}$ In March 2009, Russia announced placing a series of military bases in the region and deployment of 10,000 troops there. The Russian plan "Arktika 2020" assigns 44 billion dollars to several projects, from developing fuel and gas infrastructure to deploying troops in the Arctic. In 2009, Norway was the first to have established a military base in the circumpolar circle and until now has organized a few NATO military maneuvers ${ }^{13}$ (among others, Cold Response) in the region. Denmark is planning for its military Arctic Command to be stationed in Nuuk, Greenland. Canada's "Northern Strategy" plans to spend 2.92 billion on specialized vehicles and 680 million dollars on a new icebreaker. The United States already has military bases in Alaska but so far there no special plans to create a dedicated command there.

In the last few years, the Norwegian Navy was strengthened with five most advanced frigates equipped with Aegis anti-missile defense system. Denmark and Canada have also increased their military spending.

Still, the true challenge for all the northern countries remains foremost protecting their own sovereignty and maintaining the status quo, and only then, if at all, enlarging the sphere of economic and political influence. "A sovereignty challenge has two aspects. On the one hand, it concerns the disappearance of natural physical barriers once protecting access to the territories of mainly Russia, Canada, and the USA. On the other, it is related to maintaining own jurisdiction over the territories which so far were beyond reach of other players and whose international legal status is contested" (Osica, 2010, p. 12).

\section{Who does the Arctic belong to?}

At the beginning of the $20^{\text {th }}$ century, the countries bordering with the Arctic divided it among themselves and the delimitation was based on the so-called sector line boundary, with the North Pole as its reference point (see Tarnogórski, 2013). According to Russia and Canada, the sector principle traces longitudinal parallels from borders of countries adjacent to the Arctic Circle and to the North Pole, assigning the sectors so formed to the neighboring nations. Then the entire High North, including the Arctic, would be divided into five wedgelike sectors. Such a solution is rejected by the United States, and for obvious reasons, also Norway, Iceland, Sweden and Finland object to it.

Contrary to the Antarctic, there is no single comprehensive legal regime

12 A very interesting and much pertinent material on the subject can be found in Kubiak, 2013.

13 More on the subject of NATO and the Arctic in Security in the High North, 2013. 
governing the Arctic, but it is still subject to general regulations for seas and oceans defined in the United Nations Convention on the Law of the Sea (UNCLOS) of 1982, which became binding on November 16, 1994. Alongside UNCLOS, a number of other international treaties and customary laws also constitute the Law of the Sea. Among the more important treaties in the Arctic context are the 1958 Continental Shelf Convention [in force since 1964] ${ }^{14}$ and the 1994 Agreement relating to the implementation of Part XI of the UNCLOS ${ }^{15}$ regulating the deep seabed mining activities. Pertinent are also the shippingrelated treaties of the International Maritime Organization (IMO) (more in Czarny; Wawruch, 2008).

The 1982 Convention establishes that coastal states have sovereign rights over natural resources in a 200-nautical mile zone (among others Pieńkowski, 2008).

Figure 1: Territorial sovereignty of countries according to he United Nations Conference on the Law of the Sea

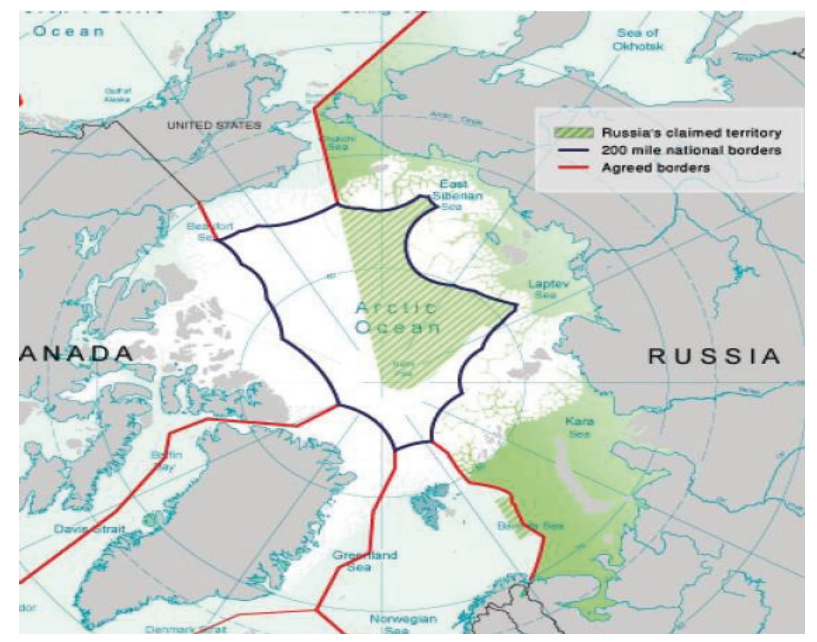

Source: Srbija danas, 2013

According to Article 76 of the United Nations Convention, however, the

14 The United Nations Convention on the Continental Shelf [the Convention] was agreed to in Geneva on the 29 April 1958. See: Journal of Law, 1964.

15 The agreement relating to the implementation of Part XI of the United Nations Convention on the Law of the Sea of December 10, 1982, drafted in New York on July 28, 1994. See: Journal of Law, 2002. 
continental shelf can be extended to 350 nautical miles. When the continental shelf goes beyond the Exclusive Economic Zone (EEZ), nations may also claim limited sovereignty over seabed resources in that area, known as the Extended Continental Shelf (or ECS) which effectively can reach out to 350 nautical miles from the shoreline. Coastal states have to submit information, based on scientific and technical evidence, to the United Nation Commission on the Limits of the Continental Shelf (CLCS) ${ }^{16}$ showing that the extended submarine area claimed is in fact a prolongation of its $200 \mathrm{n} . \mathrm{m}$. continental shelf (www. un.org). The Commission makes recommendation to coastal states on matters related to the establishment of those outer limits. As writes Młynarski (2010, p. 381): "The shelf borders established by a littoral country on the basis of these regulations are final and binding. The states submitting the claims to extend its national jurisdiction beyond the 200-mile boundary must do so within ten years of their having ratified UNCLOS. There is also a requirement that the claimant state must gather and present relevant science-based documentation". So far, the Russian Federation (2001) and the Kingdom of Norway (2006) submitted their claims to CLCS.

So it is the state that has the sovereign rights and control over natural resources of its continental shelf adjacent to its territory within 350 nautical miles from the coastline or 100 nautical miles from the 2500 -meter isobath (lines indicating water depth), whichever is greater. The law pertains to the mineral wealth but not fishery or aquatic resources which are property of a given state within the boundaries of the exclusive economic zone (200 nautical miles wide). Farther on starts the area of international waters in which it is permissible to carry out fishing, conduct research, lay pipelines, and plant flags but it is forbidden to conduct exploration and exploitation of natural resources in, on or below the seabed without the permission granted by the International Seabed Authority (ISA). The problem is that the very center of the Arctic is actually international waters. U.S. did not ratify the UN Convention on the Law of the Sea, nor did many other countries. The claims to the continental shelf have already been submitted or will be submitted soon by all Arctic states.

When deliberating on the High North, if one considered the international status of the deep seabed, than the region would be subject to the common heritage of mankind principle ${ }^{17}$ through the provisions of the Convention

16 Established under the provisions of Annex II to UNCLOS.

17 According to one theory, no nation could achieve sovereignty over the Arctic (res nullius), and according to the other (res communes), every nation shares in undivided sovereignty over the area. On February 20, 2009, at the consultation meeting of legal advisors to the ministries of foreign affairs of Russia and Canada, both parties agreed that UN Convention on the Law of the Sea is the main legal instrument for the Arctic and 
stating that in the zone of the Arctic Sea it is the freedom of navigation in the high seas which reigns.

As writes Jakobson (2010, p. 13), there are people who emphasize that the Arctic is not the backyard of any country or group of countries, so it is in the interest of mankind that all states can share the Arctic. According to this theory, it is necessary to protect the balance between the interests of states with shorelines in the Arctic Ocean and the shared interests of the international community, as the Arctic is not a "private property" but the inherited wealth of humankind (Wright, 2011).

The political question is who does the Arctic belong to? In the running there are Russia, Canada, USA, Norway and Denmark. The so-called "Arctic Five" undoubtedly have rights to the Arctic. These countries all border with the Arctic and therefore all have some claim to areas of the seafloor under the ice ${ }^{18}$. Młynarski (2010, p. 379) rightly stresses that "according to international law, the acquisition of sovereignty over unclaimed territory depends on its longterm effective occupation and control". "Under international law, no country currently owns the North Pole and the surrounding area as they are the common wealth of humankind and do not belong to any one country. How can one claim such an unreal place? Can one own some mathematical formula or equation, or the point of intersection of the Earth's axis and the Earth's surface? (The two points where the rotation axis meets the surface of the Earth are known as the North Pole and the South Pole.) The North Pole, also known as the Geographic North Pole or Terrestrial North Pole, is subject to the caveats explained below, defined as the point in the Northern Hemisphere where the Earth's axis of rotation meets its surface. All lines of longitude converge there so its longitude can be defined as any degree value. At the North Pole, where the sun rises and sets only once per year, all lines of longitude, and hence all time zones, converge. There is no permanent human presence at the North Pole and no particular time zone has been assigned to it. Polar expeditions may use any time zone that is convenient, such as Greenwich Mean Time, or the time zone of the country from which they departed. What a beautiful example of geological and geographical indivisibility that is" (Lapogue, 2010).

Issues concerning the exploitation of marine resources of the High North and of the seabed, as well as navigation problems, are regulated under international

there is no need to develop a new treaty especially for this region.

18 Barrat in The melting of the Artic http://www.experimentation-online.co.uk/article. php?id=1347, also rightly says that we must not forget about the indigenous peoples of the Arctic, about the Inuit and the Sámi, whose claims to the land and its resources are progressively heard more and more often. 
law without any need to create special regulations for the subregion (The Ilulissat Declaration, 2008). Such a position was adopted by the "Arctic Five"the USA, the Russian Federation, Canada, Norway and Denmark - in the Ilulissat (Greenland) Declaration issued by the ministries of foreign affairs of 28 May 2008.

Such an approach is very optimistic. In addition, as mentioned before, the region has already been legally and (geo)politically divided by the national borders of the eight states. The circumpolar North [also called the Arctic] of the beginning of the 21 st century is a stable and peaceful region without wars and armed conflicts. This is due to the existence of a level of political will and the agreements based on significant international and inter-regional cooperation both within and pertaining to the region. "Furthermore, within the region a number of innovative political and legal arrangements have been developed, while certain devolution of power has also taken place, based on the human capital store of educated and skillful peoples" (Heininen, 2007, p. 4).

The High North in recent years has become a target area for the growing economic, political and military interests of both the regional states and actors from outside the region, meaning on the one hand the major and growing powers such as Japan and China, and on the other the new international actors such as trans-national corporations and international environmental NGOs. One result of all of these factors and dynamics is that in these northernmost regions of the globe significant and rapid environmental, geo-economic and geopolitical changes occur. All of that, in my opinion, requires particular concern, especially when keeping in mind the security issues.

The exploitation of natural wealth will, obviously, belong to the countries exercising sovereign control over the territories in question. Demarcation of the borders has been established and the boundaries are undisputed and commonly recognized. As regards that, the Arctic political and legal status is quite different from the one in the Antarctic which in contrast needed an international treaty. There are hardly any territorial issues in the Arctic, and if they appear, they are of multidimensional character. This means in practice that that the division of the sphere of influence is not the only reason for the ongoing competition among the interested parties, but disputes are compounded by the difference in opinions regarding free passage through the Straits, territorial control over small islands, or another delimitation of the borders. They may at the moment appear trivial and have the outward appearance of "diplomatic squabbles" if not for the fact that together with disputes about the control over natural resources, they may in the future become a source of something much more serious. If we were today to point out the areas of major 
contention or unresolved territorial disputes, also the potential tension points in the High North, the list would include the following:

"- the dispute over the Northwest Passage between Canada and the United States; Canada claims that the passage is its 'internal waters,' which is not recognized by the US demanding the internationalization of the Passage by arguing that the passage is indeed an international Strait as are the Suez or Panama Canals,

- the Danish dispute with Ottawa over the ownership of Hans Island. Hans Island is located in the middle of the Nares Strait which is a strategic waterway and the ownership of it means control over maritime traffic in the entire strait,

Figure 2: Danish-Canadian War on Hans island

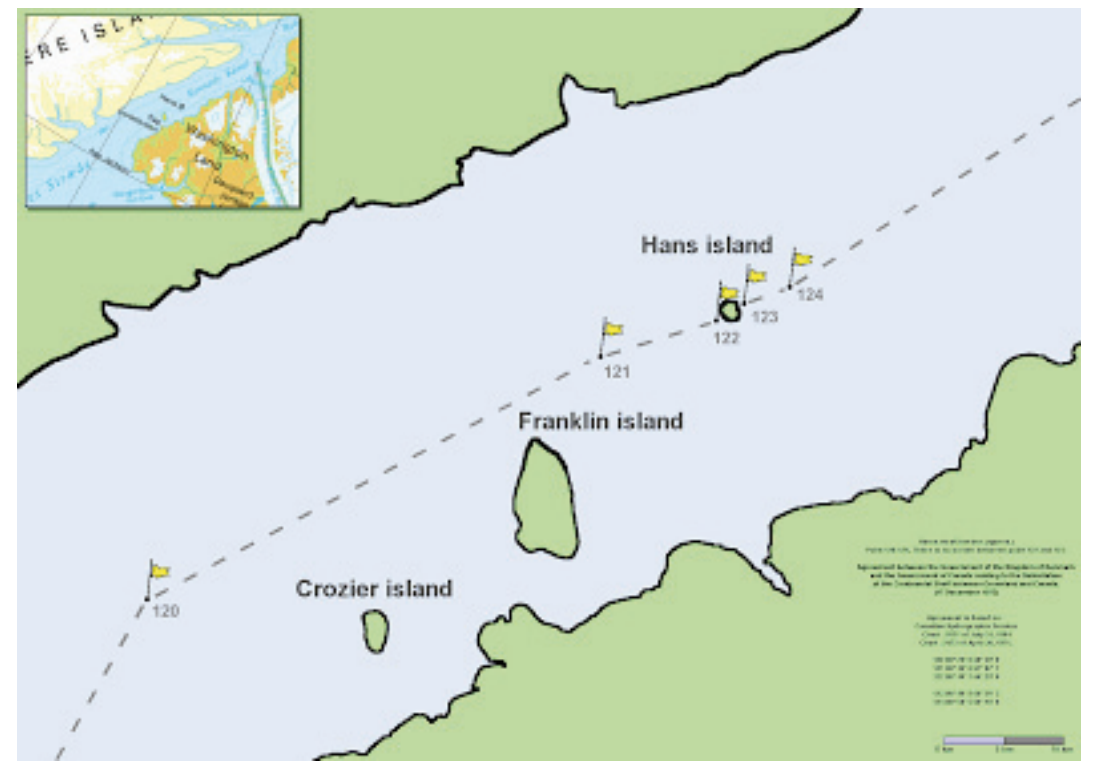

Source: Kronika montrealska, 2012.

- the Canada/US Maritime Delimitation dispute in the Beaufort Sea; there is a problem with delineating the border along the $141^{\text {st }}$ meridian of west longitude as both countries see it differently" (Bafia et al. 2012).

Should it actually come to drilling and extraction, one may or even should expect disputes over several parts of the shelf, and particularly suspicions that one side exploits the deposits on the other side. However, these will be potential disputes among the members of the Council and within the framework of the United Nations Convention on Law of the Sea. Nobody from the outside will 
be able to squeeze into the Arctic any more.

According to some politicians and legal international experts, the problem of legal protection and governance of the entire region is extremely difficult and practically unmanageable. There are simply "too many fingers in the pie" and too many frameworks and institutions. O. Schram Stokke ${ }^{19}$ is of the opinion that the best answer would seem to be a flexible approach to norm-building that seeks productive interplay with existing institutions. There already exists a legal regime, and although it is not a binding one but it can be strengthened (NRK News, 2008). That train of thought was clearly followed by Norway and Denmark who invited the interested parties to a meeting in Greenland (May 28, 2008), whose objective was to "emphasize that law and justice pertain also to the Arctic Region... We should follow the direction towards civilizing norms and applicable regulations, and not towards anarchy" (Summary of the Norwegian Press, 2008).

\section{The need for international cooperation and coordination}

The "Megatrends" (see Megatrends in the Arctic, 2012) have the potential to transform societies across social categories and at all levels, from individuals and local-level players to global structures, and eventually to change our ways of living and thinking. They synthetize the most current opportunities and challenges in view of the changes and tendencies occurring in the High North. They also suggest that in the context of the potential for exploitation of natural deposits and the development of new navigation and trade routes, as well as the consequences of climate warming, it seems absolutely necessary to point out the growing importance of the Northern Regions for the international cooperation.

The economic interest reflects the global attentiveness to the region, and the political interest and the increased military presence pose a challenge not only to the stakeholders. All that breeds worries resulting from the traditional problems of the High North: political and economic rivalry, and the presence of military installations and fleets of warships (the heritage of the Cold War). All of these aspects, taken jointly or separately, may one more time become a source of threats to the stability and development of the region in its new geopolitical context.

The increased activity in terms of opportunities and needs of exploitation of natural resources in the High North provides also, regrettably, the basis

19 Political scientist and expert on the Arctic at F. Nansen Institute in Oslo. 
for divergence of interests and even conflicts among the indigenous peoples in individual Arctic states and the industry of exploitation and processing of raw materials. It becomes particularly visible if the state has not settled with indigenous people their legal rights and claims on their traditional lands. It is then when real problems emerge within the sphere of the national and international laws. According to some experts, the region is doomed to conflict and it is an area as demanding as the climate there.

The afore-mentioned approaches and opinions hardly make one optimistic about the expected developments in the High North. Contrary to those somewhat ominous predictions, the social and economic developments in the High North, and in the Arctic region in particular, have become a very important topic of political dialogue and discussion both globally and regionally, as well as internally in individual states. The discussions clearly point out to the need for coordination of international activities and actions indispensable for achieving effective resolution of issues in the region. This is fully confirmed by O. Osica (2010, p. 20) who writes: "During the Cold War, the High North was a 'strategically frozen' area. The change of the strategic context after 1990 brought about the cooperation between those countries. However, the cooperation has not solved the legal and political disputes; neither has it accomplished the demilitarization of the sub-region. But it certainly has created better foundations for a political dialogue". The very starting of such a dialogue is quite phenomenal considering that, for example, Norway and Russia fought over supremacy in the region as early as at the end of the Middle Ages and fairly recently had a serious dispute over the common border in the Barents Sea.

Indeed, the developmental processes in the Arctic seem to gain momentum and in order to meet many of the new challenges there appears a clear need for facilitating international actions. In the contemporary world, international cooperation is absolutely mandatory, be it only for the fact that no individual state is practically able to meet all the challenges alone. In international politics, there emerged a new phenomenon of replacing one major global threat with several different dangers which allows for a new approach now that the security is no longer perceived entirely in a military context. That seems to provide an optimistic starting point for the hope that the race for the North Pole will not end in a military confrontation.

The strong involvement of the Nordic states in the Arctic is perceived as natural. From their perspective, in the few upcoming years the High North will pose the biggest challenges, and particularly in three areas: climate changes, 
natural resources (mostly energy-related) and renewable resources (fisheries), and Russia's ongoing great transformation. They fully realize that the major player in the region today is the Russian Federation which has the longest coastline of the Arctic nations and possibly the most extensive experience in acting in these extremely difficult conditions. Moreover, Russia has 18 icebreakers (which is more than the all the Arctic states combined). Because of that Norway and all other Nordic states are adamantly in favor of including Russia in all aspects of the cooperation. The basic adapted principle is that the traditional perception of Russia should be abandoned: Russia should not be part of the problem but a part of the solution. It is the more so as Russia so far had shown itself as a good partner in the regional cooperation forums. The Nordic states also believe that cooperation in the Arctic Region must be open to new partners and cannot be restricted only to the Arctic states. The strategy of openness to all the interested parties was endorsed by Norway and other Nordic states in their respective presidencies of the Arctic Council. The High North was one of the main points of the report on challenges of the Nordic Cooperation on Foreign and Security Policy prepared by Thorvald Stoltenberg, presented and published on February 9, 2009 (see Nordic Cooperation, 2009). In the assessment of this group, in spite of the increased interest in the High North and the exploitation of its resources, the key issue is maintaining a low threat level in the region (the principle of: High North - Low Tension).

The group's initiatives are developed mainly within the Cooperation Programme for the Arctic [the Nordic Council of Ministers] which formulates projects and actions (see www.norden.org). In this unique and much vulnerable region, the Nordic states have not only the vested and obvious interest but also a long history of solving problems in a joint way. Denmark, Iceland, Norway and the Faroe Islands reached an agreement (in 2006) on the disputed area in the North Atlantic, south-east of Spitsbergen. "The point was that according to the law of the sea, all four involved states could make claims to it, but they finally reached an agreement" (see Topmøde ... 2008). In 2006, Norway and Denmark signed a historic agreement on the delimitation of the continental shelf and the maritime boundary between Svalbard and Greenland (the area of some $150000 \mathrm{~km}^{2}$ ) (Aftenposten, 2007). The division was based on the principle of the median line, the very same presented by Norway in its negotiations with Russia in the dispute over dividing the Barents Sea. Their agreement, however, does not include settling the stewardship of the continental shelf and sea waters. In essence, it means also that it does not pertain to the issues regarding the resolutions of the Svalbard Treaty giving the other signatory countries (there are 40 of them) "equal rights" to certain economic activities "on land and in 
the territorial waters" of the archipelago (Dagsavisen, 2007).

The Norwegian claims of exclusive rights to the Svalbard archipelago are not the only problem. Canada and Russia maintain that the water passages close to their northern coasts are their territorial zones and wish to control and regulate shipping in the Northwest Passage and the Northern Sea Route. In turn, the US and EU maintain that the Arctic waterways are international straits through which the right of free passage should be assured.

Everything seems to lead to a complicated prospect of clear and quick solutions. The right one, although possibly difficult in the sense of negotiations, was presented by the ministers of foreign affairs of Norway and Denmark, J. G. Støre i P. S. Møller [at the meeting in Oslo on June 15, 2008], who said that when other countries ask them about a legal framework concerning the matter, they may only give the following answer: "Yes, the Law of the Sea and the International Law" (see www.aftenposten.no).

Faced with potential conflicts, the interested states engaged in a dialogue in multilateral fora. On May 28, 2008, in the Ilulissat Declaration, the coastal Arctic states expressed their willingness to cooperate and spare no effort to resolve outstanding disputes in accordance with the Law of the Sea (similar declarations were made at the forum of the Arctic Council). The joint declaration talks about the challenges related to climate change and acknowledges that the international legal framework applies to the Arctic Ocean. Although it is only a declarative statement, it certainly proves the will for cooperation by the "Arctic Five." It also rejects all disputes which may be a source of potential conflicts. A good example of institutionalized cooperation of the Arctic states and the indigenous peoples of the High North is the Arctic Council which is an intergovernmental forum for cooperation and an attempt at coordinating joint efforts for the common benefit. The Council is splendidly complemented by the "Arctic Frontiers" which are annual conferences of the Arctic states providing a forum for discussion also for other countries interested in the future of the North. ${ }^{20}$ One must not forget about the special role of UN in maintaining international peace in the region. It was the United Nations that has planned an international conference for the year 2020 at which, after considering all the submitted petitions by the UN Commission on the Limits of the Continental Shelf, the recommendations to coastal States on matters related to the establishment of the outer limits of the continental shelf beyond

20 The Arctic Frontiers is an international arena addressing development in the Arctic. The forum supports open and independent dialogue between countries, building cooperation with the indigenous peoples of the High North, and implementation of new solutions to protect the delicate Arctic environment and ecosystems. 
200 nautical miles will be made and thus the Arctic will be finally divided into spheres of influence.

On September 15, 2010, in Murmansk, the Russian Federation and Norway reached an agreement ${ }^{21}$ and signed the bilateral treaty on maritime delimitation and cooperation in the Barents Sea and the Arctic Ocean. The agreement regulates the division of the disputed area of 175000 square kilometers which is rich in deposits. The work on the agreement took close to 40 years of negotiations. The peaceful negotiations were firmly based on principles of the international law of the sea which allowed overcoming the zero-sum attitude (or all or nothing) and helped to focus on negotiations leading to a solution satisfying both sides. The agreement clearly shows that in the long perspective the countries vitally interested and wishing to achieve a lasting agreement can actually generate significant added value. This value is of tremendous importance not only to the stakeholders but above all to the entire international community. Such was the case of the Russian-Norwegian agreement on the maritime delimitation in the Barents Sea and the Arctic Ocean. "The benefits for each country due to striking this compromise already surpass potential profits in the future which would have resulted from attempts of securing a larger territory entirely for one side" (Wspólne wyzwania, 2010). Although cooperation is not always easy, achieving this agreement opened the doors for collaboration in other fields: scientific cooperation, the development of common standards for maritime safety, environmental protection, and even the cooperation on the exploitation of raw materials. The Russian side highly respects the competence of the Norwegian oil and gas industry today. "In the oil sector, Norway has developed unique competency; therefore, we positively perceive further potential cooperation of Russian and Norwegian companies in joint oil projects not only in Russia and Norway but also in other parts of the world. We sincerely hope that in the near future such a development will take place because it is of great significance. "22

Norway and Russia, due to their geographical location, geological conditions and the worldwide growing demand for energy seem to be heading

21 The agreement facilitates off shore licensing in the formerly disputed area, which in turn allowed for the cooperation of energy companies there.

22 The statement by Sergei Oganesyan, head of the Russian Federal Energy Agency; quoted after: Aftenposten, January 26, 2007. It should be added that Norsk Hydro sought exploration licenses in Libya together with Gazprom. Norway's Hydro and Russia's Lukoil have joined to explore oil fields in Iran. Gazprom, Statoil and Norsk Hydro signed a cooperation agreement at the end of 2006 on the prospecting, development and exploration of offshore fields in the Barents Sea. 
towards a special form of cooperation and perhaps even towards a new kind of "alliance" in the North. Norwegians are a nearly perfect candidate because they share a common geographical border with Russia and have the necessary technology needed in the Northern territories. In practice, they also are deeply interested in the establishment of privileged energy partnerships and becoming Russia's priority partner in the North. There exist also plans of developing a Norwegian-Russian agreement on managing the Northern Regions. Although the Norwegians are aware of further competition to define the international position of a country by means of energy, they believe it not to be an obstacle in the Norwegian development of energy cooperation. Is Norway, however, fully aware of the potential reactions of political nature? Today, one may surmise that the prospects of new benefits from energy resources in the North [regardless of their state ownership] may somewhat blur the complexity of the political picture for the Norwegian business leaders as well as the politicians.

In today's political climate in the Arctic, cooperation rules over conflict or even aggressive competition. In the long run, however, maritime borders may pose problems difficult to solve. In addition, there are also risks connected with the increasing international tension brought about by environmental, social and economic changes in the region.

\section{Conclusion}

The world of the North can be truly fascinating. One finds it hard to resist its unique atmosphere, the wild and barely accessible landscapes, the emptiness, the loneliness, and the omnipresence of nature filling all senses to the brim.

This yet not fully explored realm is an area of great hope and in numerous cases also of challenges difficult to identify and outcomes impossible to predict. They assume a very special significance as they concern the vital zones of our globe in which the consequences of what is happening may become an extremely complex combination of opportunities on the one hand and almost immediate threats on the other. Put differently, they may impact international relations on a scale greatly surpassing the interests only of our hemisphere.

This region is the European High North and the Arctic in particular. It is beyond doubt one of the key areas of the global system, in which the melting of ice and permafrost seems to open new maritime transport routes and allow access to the previously unavailable deposits of natural resources. This creates a potential source of disputes or even conflicts in the process of establishing the ownership of natural resource deposits and the delimitation of the boundaries. Hence the area has been extremely active and is characterized by a certain 
nervousness displayed by the states of the region.

One should not be deluded that the emerging conflicts in the North can be solved entirely through competent diplomacy. The progressive militarization, however, is also a mistaken strategy. The debate on the future developments in the North must not exclude the public opinion. Should the decisions be made in the form of administrative strategy, and without social acceptance, that strategy will simply fail and may turn into the unfortunate combination of the theme of climate change and jingoist security rhetoric. In turn, sweeping the problem under the carpet will not stop the course of history or the global warming. It is not enough to talk only about a "strategically important area."

The activity in this vulnerable region has grown in the last decade much more rapidly than anyone expected. The more time is devoted to the portioning of the Arctic territories, the higher the tension will grow. Hence there is a necessity of investing into patient dialogue as a key ingredient in building mutual trust between partners on the global arena. Without the indispensable trust which is capable of predicting and lowering future tensions, the parties will be unable to engage in creative discussions obligatory in solving problems. Moreover, it is a unique chance to design and build mechanisms for promoting security in the region. Such fora for discussions and actions, where experts and politicians from the eight Arctic states meet, are already in place: one is the Arctic Council and the other the Barents Euro-Arctic Council [BEAC]. They are vital for building dialogue, trust and transforming knowledge of the region into political decisions. Strengthening and supporting these organizations seem to be a reasonable investment because cooperation is of utmost value. Admittedly, it requires good will, engagement and time, but the returns can bring the probability of developing joint solutions which in the long run will benefit all the involved parties.

\section{References}

AFTENPOSTEN, February 21, 2007.

BAFIA, M.; BARTOSIK, A.; DRWAL, M.; GAJDZICA, M. 2012. Arktykaprognoza wybuchu wybuchu potencjalnego konfliktu zbrojnego o surowce naturalne.

Retrieved February 05, 2013 from http:/geopolityka.org/analizy/mariuszbafia-agata-bartosik-magdalena-drwal-michal-gajdzica-arktykaprognoza-wybuchu-potencjalnego-konfliktu-zbrojnego-o-surowcenaturalne.

CHEDA, R. 2013. Zimna wojna o bogactwa Arktyki. Jak daleko posunie sie 


\section{Rosja?}

Retrieved March 20, 2013 from http://konflikty.wp.pl/ kat, 132916,title,Zimna-wojna-o-bogactwa-Arktyki-Jak-daleko-posuniesie-Rosja,wid,15400614, wiadomosc.html.

CZARNY, W.; WAWRUCH, R. 2008. Międzynarodowa Organizacja Morska. Zadania, Struktura Organizacyjna i Metody Pracy.

Retrieved July 15, 2013 from http://www.bhmw.mw.mil.pl/zasoby/ph/pliki/ PH_4_Czarny.pdf

DAGSAVISEN, February 21, 2007.

EĐVARĐSSON, I. R. 2007. Demographic Changes, Labor Migration and EU-Enlargement - Relevance for the Nordic Regions. Stockholm: Nordregio.

EEA. 2001. Environmental Signals 2001, Environmental Assessment report No. 8. Copenhagen: European Environment Agency.

Retrieved December 03, 2012 from http://www.eea.europa.eu//publications/ signals-2001.

JAKOBSON, L., \& Stockholm International Peace Research Institute. 2010. China prepares for an ice-free Arctic. Solna, Sweden: Stockholm International Peace Research Institute.

JOURNAL OF LAW of 1964, no. 28, item 179 in force since July 27, 1964.

Retrieved May 09, 2011 from http://prawo.legeo.pl/prawo/konwencjao-szelfie-kontynentalnym-sporzadzona-w-genewie-dnia-29-kwietnia1958-r/.

JOURNAL OF LAW of May, 20, 2002.

Retrieved August 14, 2013 from http://www.lex.pl/du-akt/-/akt/dz-u-02-59544.

ŁUSZCZUK, M. 2010. Perspektywy żeglugi arktycznej. In: Przeglad Morski, 02/2010. Retrieved September 15, 2013 from https:/docs.google.com/ viewer? $\mathrm{a}=\mathrm{v} \& \mathrm{q}=$ cache:JhJMc7ROAYkJ $:$ www.polska-zbrojna.pl/index. php?option\%3Dcom_rubberdoc\%26view\%3Ddoc\%26id\%3D296\%26for mat $\% 3$ Draw $\% 26$ Itemid\%3D111+trimarany+pionowe+wyrzutnie \&hl=pl $\& \mathrm{gl}=\mathrm{pl} \& \mathrm{pid}=\mathrm{b} 1 \&$ srcid=ADGEESh3K3_K2nEriOcG51OXU6WinzPto91q BItmQADgK9DduKLDWKkktbK86iOd_9BE04hutPZbnUlZGB_rLp6M 7NFbbBSD1XRPyUSHQqqp0PADu9DX1Ey2OwiKPv84DK_P_y\&sig= AHIEtbSnFSDCqPaanUd1a-NtU5G_8dtMOw.

KETELS, C. 2008. Global Pressure - Nordic Solutions? The Nordic Globalization Barometer 2008. Copenhagen: Nordic Council of Ministers. KRONIKA MONTREALSKA. 2012. 
Retrieved from http://kronikamontrealska.com/2012/08/03/wojna-dunskokanadyjska-o-wyspe-hansa/

KUBIAK, K. 2013. Arktyka. Między dziedzictwem zimnej wojny a wspótczesnościa. In: Bellona no. 2/2013(673), Warszawa, pp. 51-75.

LAPOUGE, G. 2010. Bogactwa w lodowym skarbcu, kto je dostanie? Le Monde diplomatique - Polish edition.

Retrieved March 20, 2013 from http://konflikty.wp.pl/ kat, 1020225 , title, B ogactwa-w-1odowym-skarbcu-kto-jedostanie,wid,13043886, wiadomosc.html.

MEGATRENDS IN THE ARCTIC. 2012. Megatrends in the Arctic - New inspiration into current policy strategies. Report from Nordic Council of Ministers seminar at Nordregio $29^{\text {th }}$ May 2012. Nordregio Working Paper 2012: 8,

Retrieved from: http://www.nordregio.se/en/Publications/Publications-2012/ Megatrends-in-the-Arctic/

MŁYNARSKI, T. 2010. Arktyka - nieodkryty spichlerz energetyczny świata. Politeja 2010, nr 13.

MŁYNARSKI, T. 2011. Bezpieczeństwo energetyczne w pierwszej dekadzie XXI wieku. Mozaika interesów i geostrategii. Kraków: Wydawnictwo Uniwersytetu Jagiellońskiego.

NORDIC COOPERATION. 2009. Nordic Cooperation on Foreign and Security Policy, Proposals presented to the extraordinary meeting of Nordic foreign ministers in Oslo on 9 February 2009.

Retrieved October 25, 2012 from https://www.regjeringen.no/globalassets/ upload/UD/Vedlegg/nordicreport.pdf

NRK News, June 14, 2008.

OSICA, O. \& Centrum Europejskie Natolin. 2010. Daleka Pótnoc jako nowy obszar wspótpracy i rywalizacji. Warszawa: Centrum Europejskie Natolin.

PIASECZNY, J. 2010. Spory o podział Arktyki, The Issue 14/2010.

Retrieved May 01, 2013 from http://www.przeglad-tygodnik.pl/pl/artykul/ spory-o-podzial-arktyki.

PIEŃKOWSKI, A. 2008. Zimna wojna o Arktykę. 24/2008. Retrieved July 10, 2013 from http://www.wprost.pl/ar/131321/Zimna-wojna-oArktyke/?pg=1.

SECURITY IN THE HIGH NORTH. 2013. Security in the High North: NATO's Role, NATO Parliamentary Assembly Political Committee, 071PCTR 13 E, 28 March 2013. 
SRBIJA DANAS. 2013.

Retrieved from: http://www.srbijadanas.net/rusija-pocela-razmestanjevazdusno-kosmicke-odbrane-na-arktiku/

SUMMARY OF THE NORWEGIAN PRESS, April 16, 2008.

TARNOGÓRSKI, R. 2009. Roszczenia do Arktyki - aspekty polityczne $i$ prawne. Biuletyn no. 21 (553), April 17, 2009. The Polish Institute of International Affairs, Research and Analyses Department, Warszawa.

THE ILULISSAT DECLARATION. 2008. Arctic Ocean Conference, Ilulissat, Greenland, 27-29 May 2008.

Retrieved September 03, 2012 from http://www.oceanlaw.org/downloads/ arctic/Ilulissat_Declaration.pdf.

TOPMØDE... 2008. Topmøde på Grønland om Arktis norden, May 28, 2008. Retrieved March 03, 2012: http://www.norden.org/webb/news,

TOTAL ECONOMY DATABASE. 2008. The Conference Board and Groningen Growth and Development Centre.

Retrieved April 08, 2008 from https://www.conference-board.org/data/.

TRUC, O. 2008. Copenhague accorde au Groenland le partage des revenus espérés du pétrole arctique. Le Monde. 21.3. 2008

UNCLOS. Article 56, Rights, jurisdiction and duties of the coastal State in the exclusive economic zone.

Retrieved from

http://www.un.org/depts/los/convention_agreements/texts/unclos/part5.htm.

UNCLOS. Article 77. Rights of the coastal State over the continental shelf http://www.un.org/depts/los/convention_agreements/texts/unclos/part6. htm.

WRIGHT, D. C. 2011. The dragon eyes the top of the world: Arctic policy debate and discussion in China. Newport, R.I: U.S. Naval War College, China Maritime Studies Institute.

Retrieved from https://www.usnwc.edu/Research---Gaming/ChinaMaritime-Studies-Institute/FacultyBooks/Publications.aspx.

WSPÓLNE WYZWANIA W ARKTYCE. 2010. [J. G. Stoere and S. Lavrov statements]. (October 1, 2010). Rzeczpospolita.

Retrieved December 12, 2012 from http://www.rp.pl/artykul/543343. html?print=tak. 